УДК 334.732.4:94(477)

DOI: 10.31651/2076-5908-2019-2-97-104
ZEMZYULINA Natalka,

Doctor of History, professor at the

Department of World History and

International Relations at the Bohdan

Khmelnytsky National University of

Cherkasy

Orcid ID: 0000-0002-9028-2093

e-mail: alkatan@gmail.com,

KORNOVENKO Sergey,

Doctor of History, professor at the

Department intellectual property and civil

law the Bohdan Khmelnytsky National

University of Cherkasy

Orcid ID: 0000-0002-6268-2321

e-mail: s-kornovenko@ukr.net

\title{
THE ROLE OF NATIONAL COOPERATIVES IN THE ECONOMIC TRANSFORMATION OF EUROPEAN COUNTRIES IN THE FIRST THIRD OF THE XXth CENTURY (THROUGH THE EXAMPLE OF GERMANY)
}

This study focuses on the peculiarities of the cooperative movement in Germany. It is stated that if in the sphere of consumer cooperation Germany succeeded Great Britain, in the sphere of credit cooperation it was the birthplace of two of its types - the urban credit cooperation of G. Schulze-Delitzsch and the rural credit cooperation of $R$. Raiffeisen. The cooperation was spread, on the one hand, taking into account national peculiarities of the conditions of the consumer cooperation, which at the same time acquired the features of Schulze-Delitzsch's procurement-distribution or savings and loan cooperatives, while on the other, by the development of a specific agricultural cooperation on the principles of Raiffeisen. It is noted that despite the successful development of agricultural cooperation in Germany, in the 1930s its role gradually diminished with the rapid industrialization and urbanization of the country.

Key words: Germany, cooperative movement, Shulze-Devitzsch's saving and loan cooperatives, Raiffeisen's cooperatives.

The development of capitalism in European countries contributed to the destruction of the traditional forms of organization of society that existed in previous centuries. Industrial revolution, the accumulation of capital, and the simultaneous deterioration of the living conditions of the general population of European countries have provoked powerful revolutionary upheavals. Exacerbating of contradictions between the individual social groups of the European society and finding ways to resolve it were the focus of public and political figures of the time. The actuality is due to the fact that cooperation and cooperative movement play a particularly important role in the transition periods, during the so-called transition economies and the emergence of civil society. World experience of economic self-organization of the population today is extremely relevant for Ukraine.

The purpose of this study is to show, on the example of Germany, how national cooperation in transition period can be a significant component in creating a stable national economic system.

The historiography of the question. The history of the emergence and development of European cooperation was actively analyzed at the end of XIXth - in the first quarter of XXth century. During this period the works whose authors were active participants in the European cooperative movement were published. Among them are groundworks and analytical researches by: A. Antsiferov, S. Borodaievsky, V. Totomiants, M. Tugan-Baranovsky and others. In Soviet 
historiography, however, the problems of the development of foreign cooperation have never become the subject of special historical research. Some sort of adjustment of foreign cooperation was made in connection with the partial liberalization of the Soviet regime in the 1950s. Among Ukrainian researchers we may name the works of: L. Fain, V. Kabanov. It is worth noting the works of modern Ukrainian scientists O. Krapivin, M. Zhurba, O. Kramar, O. Berendeieva, O. Vlasova and others.

Presenting the main material. By the end of XIXth - beginning of XXth century various forms of urban and rural cooperation have spread among European countries: consumer, credit, integrated agricultural, housing, etc. England was the pioneer in this sphere. Industrial uplift that lasted in the country in the mid-nineteenth century led to a sharp increase in the number of factory workers, changed their proportion with the artisan population of the country and identified a predominantly industrial path for the further development of British consumer cooperatives. The main stimulus for the expansion of consumer cooperation was initially the desire to overcome the system, according to which employers paid wages not in money, but in checks for which in their stores workers were forced to buy goods of poor quality at significantly inflated (by $20-30 \%$ ) prices, comparing to market [1,22-25]. The increase in the number of consumer cooperatives has contributed to the emergence of firstly territorial and then - national associations. Thus, in 1863 The North of England Cooperative Industrial and Savings Society for the Wholesale Purchases was established. In ten years it has become the nationwide "English Society for Wholesale Procurement" [2, 46-49; 51-52; 86-88]. By the early 70's of the XIXth century several cooperative centers emerged in the UK - The Cooperative Insurance Society, The Scottish Wholesale Purchasing Society, The Cooperative Central Bank. Consolidation has accelerated the pace of development of the country's cooperative movement. While by $18721,2 \%$ of population in England and Wales, and 1,1\% in Scotland were cooperated, in 1889 these figures increased to $2,8 \%$ and $3,8 \%$ respectively, and as of 1914 reached $-5.7 \%$ and $8.6 \%[3,126]$.

These processes were completed in the late nineteenth century with the transformation of the cooperative movement from a powerful socio-economic force into an organization with diverse socio-political and cultural and educational functions. The Cooperative Union became the coordinator of the non-trading activities of the British cooperative, which gradually formed a network of committees specialized in specific areas of work: educational, publishing, propaganda and exhibition. British consumer cooperation became a model for the rest of European countries by the end of XIXth century [4, 187].

Due to the later start of industrialization, consumer cooperation in France, Germany and other Western European countries has taken specific forms. This primarily concerned its social composition. Contrary to the English consumer cooperation, whose members were predominantly laborers since the mid-XIXth century, in Germany, and especially in France the spread of cooperation was primarily related to the small proprietors strata of cities.

Despite the existence of German urban associations since mid XIXth century, that set out to jointly purchase food products, a classic form of advanced consumer cooperation was borrowed from the experience of British Rochdale societies in the 1860s. An attempt to develop a specific German form of consumer cooperation was made in the early 1850s by H. Schulze-Delitzsch. They were created as addition to credit ones and have maintained strong organizational relationships with them for a long time. The members of these consumer societies were mostly impoverished artisans. The rapid growth of working-class consumer cooperatives, based on the British model, began in the early 60s of XIXth century and accompanied the completion of the industrial revolution in the country [5, 35-39, 47-48]. The processes of advanced industrialization and the accompanying urbanization of German society, which had transformed a predominantly agricultural country into a leading industrial state of Europe before the First World War, contributed to the strengthening of the role of German consumer cooperation in the Pan-European. However, 
the population involved has continued to be significantly smaller comparing to rural credit cooperatives, and accounted for less than a third of all cooperative residents of Germany [6, 14-16].

On the verge of World War I, the Western European consumer cooperation, the dominant position in which was occupied by British working-class cooperation, moved to the concentration stage. With the increase in turnover and the number of members, there is a decrease in the number of cooperatives due to their merger. The consolidation of the cooperative movement is happening on a national scale as well. In particular, in France in 1913, as a result of the merger of two centers of consumer cooperation, the single federation and wholesale purchasing society were formed [7, 26-27]. In the early XXth century corresponding societies have appeared in Belgium, France, The Netherlands, Austria, Finland, Russia and Norway. Their successful development brought to the consideration of the international cooperative movement the creation of the International Society of Wholesale Procurement [8, 335-336]. Developed in 1908 by the International Cooperative Alliance, the charter of the International Federation of Wholesale Procurement provided that the latter would facilitate business relations between its members and the trade of goods they produce internationally [9, 371-372]. In this way, the most powerful British consumer cooperation in the world hoped to avoid international trade brokerage.

While in the field of consumer cooperation, Germany followed the experience of the United Kingdom, which had much earlier experienced an industrial revolution and the rapid growth of the working population in cities, which accompanied it, in the field of credit cooperation it was the motherland to two of its types - the urban credit cooperation of G. Schulze-Delitzsch and the rural credit cooperation of R. Raiffeisen. During the first third of the XIXth century in Germany, the process of displacing small-scale artisan production continued, which did not withstand the competition with the factory. The proletarization of the urban population that accompanied this process increased social tension in society and caused the destruction of traditional moral values. In the search for ways out of this complex social situation, German public opinion offered its own, national variant. The founder of the German city credit cooperation was the already mentioned G. Schulze-Delitzsch, who proposed to move to the creation of production artels through the development of cooperative lending. The systematic shortage of financial resources for the purchase of raw materials and food products led Schulze-Delitzsch to choosing such a way for the development of cooperation of artisan strata in German cities. [5, 177-180].

G. Schulze-Delitzsch assumed that impoverished burghers should help themselves. He came to this conclusion based on his previous experience of charitable work among the poor. Any gratuitous assistance was spent within a short period of time, while a loan on favorable, not indentured terms, should have pushed its recipients to use the funds received effectively. The small proprietors strata of German cities, which could not get access to bank loans, proved to be an ideal environment for spreading the proposed form of cooperation. In 1859, at the initiative of Schulze-Delitzsch, the first congress, established under the principles proposed by him, of credit societies in Weimar was convened, at which the central government was elected. In 1861 G. Schulze became the Secretary of the «All-German Union of Cooperatives» of credit cooperation and was elected to the Prussian Landtag, where he was one of the initiators of the adoption of the first cooperative law in 1867 [10, 68-69]. The General Union (of Schulze-Delitzsch) numbered 956 credit and savings cooperatives ("people's banks") with about 600 thousand members as of 1910. The Union continued to include 252 thousand members of consumer cooperatives with predominantly small proprietors social composition and 137 building societies [5, 171]. In this way, unlike in Great Britain, which cooperative movement already in the late XIXth century became a classic version of consumer cooperation of the urban population, Germany due to the introduction of the system of the so-called people's banks by G. Schulze-Delitzsch, in the late XIX th century became a country of classic credit cooperation of urban population, the experience of which was taken over by the rest of the countries of Central and Southeastern Europe, where small proprietors strata made up a considerable part of the urban population. 
The spread of cooperation in the rural population of European countries was on the one hand, taking into account the national peculiarities of the conditions of consumer cooperatives, which at the same time acquired the characteristics of procurement (Denmark, Sweden, Hungary), or the Schulze-Delitzsch savings and loan companies and on the other hand, by developing a specific agricultural cooperation on the principles of Raiffeisen, modified to the needs of each individual country (Austria-Hungary, Bulgaria, Serbia, Polish lands within the German Empire). With close ties to the capacious English market and the cooperative movement developed in the country, Denmark has become a classic example of European country with agricultural and consumer cooperation. Its successful experience was positively received and embodied by the peasants of Sweden and Hungary, for who exports played an important role [5, 44-46].

However, the co-operative movement of most European countries (especially those lightly related to the world market for agricultural products) revolved around credit co-operation. Its birth, as noted, took place in Germany during 50-60's as a reaction to the growing destructive influence of usury on the peasantry and small agricultural production. The two types of credit cooperation were the Raiffeisen's "people's cash registers" and Schulze-Delitzsch's "people's banks". Despite the key common feature - the call to become a form of self-organization and stabilization of society, they had significant differences due to the social environment of their application. Raiffeisen groups excluded the possibility of involving non-peasants, while SchulzeDelitzsch cooperatives were based on the involvement of large sections of the smallholder population both in the city and in the village. The Raiffeisen societies, compared to the SchulzeDelitzsch one's, were more compact, usually consisting of several dozen members belonging to one parish. The principle of remuneration of its management had a significant influence on the scale of cooperatives. In Raiffeisen local societies, the leadership worked on a public basis, while in much larger Schulze-Delitzsch the leadership needed to be paid [11, 21-24].

The Raiffeisen societies were more democratic. They did not have any entrance fees and its members could not concentrate the shares in their hands because the latter was forbidden to pass on to anyone. At the same time, the Raiffeisen groups were more cooperatively closed, their members had neither the right to lend to non-members nor to borrow from usurers. The SchulzeDelitzsch partnerships, on the other hand, were primarily focused on profit-making by its members. They could buy shares in any other company or invest in a bank and received a substantial dividend on their own share contributions. At the same time, the Schulze-Delitzsch's "national banks" were primarily limited liability companies of members for the cooperative obligations, while the Raiffeisen's "people's cash registers" required unlimited liability of all members with their own assets [12, 22-23]. The lack of share contributions in the Raiffeisen societies was due to the fact that the members of the cooperatives were mainly poor peasants who were unable to make these contributions. Usually, the rural credit cooperative received some capital for the beginning of the activity on charity basis (from local rich, municipal bodies, church, etc.), later the main sources of its credit operations became contributions of members-shareholders and loans from private individuals, individual organizations and institutions, including cooperative unions. Raiffeisen credit companies have established as a mandatory rule the creation of a nonrevolving fund, which was not a subject to distribution even when the company was liquidated and later used to set up new cooperatives [12, 42].

Due to own seclusion and cautious attitude to the world, the Raiffeisen cooperatives sought to develop additional activities: selling and purchasing, loans were granted for long terms (several years), while Schulze-Delitzsch “people's banks" preferred short-term loans [13, 23]. For comparison, Schulze-Delitzsch partnerships were actively involved in external credit and lending to all, including "non-members", whereas the "people's cash registers" required only loans to members, and the volume of borrowed funds from outside gradually decreased [13, 23]. With a low lending rate, the creation and accumulation of undivided funds in Raiffeisen companies 
were difficult tasks, so credit companies, in addition to purely credit (accepting deposits and issuing loans), also carried out trade and intermediary transactions, which brought them significant additional revenues. In addition to financial activities, companies of this type taught members the principles of the proper sale of goods, accounting and economics [13, 71-72]. In general, it should be noted that Raiffeisen's loan offices have substantially limited the negative impact of money lenders on agriculture.

Initially, the development of Raiffeisen credit cooperatives in the German countryside was slow. The peak of their development was the end of XIXth - beginning of XXth century. Over 15 years (1887-1902), their number has increased 13 times and reached 12,000 [14, 8-9]. They were the basis of agricultural cooperation in the country. The overall level of people's cooperation reached $50 \%[14,17]$. The process of consolidation of German credit societies into regional unions ended with the unification of the General Union of Agricultural Societies in Germany in 1883 (since 1903 - the Imperial Union of Agricultural Societies in Germany) [15, 149]. In addition to the organizational consolidation of the agricultural cooperative movement, built on the principles of Raiffeisen in Germany in the early XXth century, consolidation has emerged towards the creation of a single financial institution. In 1902, the Imperial Cooperative Agricultural Bank was established. However, its bankruptcy in 1912 led to a sharp exacerbation of contradictions and the withdrawal from the Imperial Union of Raiffeisen orthodox societies [15, 158].

The peasantry constituted a majority of members in the General Union of Industrial and Business Societies (Schulze-Delitzsch). As of the end of 1911, it consisted of 620,7 thousand people. Among them: rural $-26,6 \%$; hired workers in agriculture $-2,4 \%$; artisans $-22,8 \%$; hired workers and apprentices - 7\%; dealers - 10,3\%; freelancers and civil servants $-7,5 \%$; renters and pensioners $-8,7 \%$; owners of industrial enterprises $-3,9 \%$. Thus, the smallholder groups of the German village and city formed the basis of the Schulze-Delitzsch credit cooperation $[16,14-16]$. The center of this branch of the German cooperative movement was the General Union of German Industrial and Economic Societies (Schulze-Delitzsch), which although consisted mainly of credit cooperatives, but enclose up to 240 (at the beginning of 1911) consumer societies and most of the construction cooperatives of the country [16, 27]. It should be noted that despite the successful development of agricultural cooperatives in Germany, its role in the country has gradually diminished in view of the rapid industrialization and urbanization of the country. During the period 1871-1910, the population of the empire increased from 40,8 to 60,8 million people, while rural population decreased from 26,2 to 25,8 million, moreover, the urban population, primarily engaged in consumer working cooperation, increased almost 2,5 times. The share of employed in agriculture decreased to $30 \%$ and continued to decline $[17,112]$.

The global economic crisis of 1929-1933 caused huge losses for cooperatives. Only in 1931 the total turnover of cooperative organizations decreased by $29 \%$. And during all four years of crisis, the turnover of German consumer cooperatives has decreased by $50 \%$. All the problems of the cooperative economy have intensified, competition with private capital has intensified, the pressure of private, commercial and industrial capital on cooperation has increased. Sharply reduced own production of consumer cooperatives, reduced the share contribution. Organized attacks on cooperative movement in the press increased, government harassment in taxation and legislation intensified $[18,18]$.

The deteriorating economic situation of the cooperatives became the subject of discussion of the 13th Congress of the International Cooperative Alliance, held in 1930 in Vienna. But Congress has once again become an arena of ideological struggles and has not made any significant decisions to unite the public in defense of the cooperation. In July 1933, a special international cooperative conference was held in Basel to discuss the issue of the cooperative's attitude to the economic crisis and to prepare for the World Economic and Financial Conference. The participants of the conference adopted a declaration entitled «International Solidarity of Co-operation», which 
proceeded from the fact that the global economic crisis demonstrated the failure of the capitalist system of economy and public administration, which dramatically increased the danger of war and put at risk the existence of civilization itself. The conference's decision began to refocus the international cooperative movement from economic activity to political. Consolidation of forces to fight fascism and war was needed [19, 45]. During 20-30's, fascist and reactionary regimes in Italy, Hungary, Bulgaria, Austria, and Germany pursued a policy of eliminating cooperation [20, 22]. While in Italy the fascists acted gradually, in Germany, a few months after Hitler came to power, cooperative organizations were included in the German fascist labor front. Central Consumer Cooperative Union, Christian Cooperative Union and other organizations were united into a single fascist national "Reichsbund" union [7, 186].

Conclusions. The main trends in the development of the European cooperative movement are revealed in the study. The global experience of cooperative organizations has proven their important role in economic development, especially during transformational and structural crises. On the example of European countries, it can be traced that the long-lasting systemic crises caused by the inability of the imperial authorities to adequately respond to the modernization processes of the XIXth - early XXth centuries, resulted in revolutionary upheavals in Europe in early XXth century. One of the determining factors was a failure to solve the peasant (land) issue [21, 45].

The cooperative sector contributed to the formation of multifaceted national economies, increased competitiveness of the market environment, expansion of economic activity, the combination of personal, collective and public interests. In social sphere, the mission of the cooperative sector was aimed at ensuring employment and alleviating social discrimination of the population, social protection of cooperators, strengthening the democratic foundations of society.

Germany gave impetus to the development of peasant credit cooperatives, which began to emerge and develop in other countries of the world. This was facilitated by the successful experience of the German societies, as well as the advocacy work of their ideologues, students and followers of the latter. Extremely popular was the idea of national unity of F. Liszt, as well as the application, at national level of society, of non-classical political economy (A. Smith's theory), but the economic doctrines, corresponding to national needs. It is well known that in Germany the idea of creating a national economic system was implemented by O. von Bismarck by strengthening the German nation precisely by the means of a growing national economy in which cooperation played a key role.

\section{Список використаної літератури}

1. Туган-Барановский М.И. Социальные основы кооперации / М.И. Туган-Барановский. - Москва : Экономика, 1989. - 496 с.

2. Flanagan D. 1869-1969 A centenary story of the Co-operative Union of Great Britain and Ireland / D. Flanagan. - Manchester, 1969. - 128 p.

3. Hall F. \& Watkins W. P. Co-operation: a survey of the history, principles and organisation of the co-operative movement in Great Britain and Ireland - London, 1934. - 289 p.

4. Теория кооперации / Макаренко А.П., Крашенинников А.И., Кизилевич А.В., Паламарчук В.Е., Хвостов Б.Н.. - Москва : Экономика, 1982. - 282 с.

5. Reeves J. A century of Rochdaleco-operation, 1844-1944 / J. Reeves. -London : Lawrence \& Wishart, 1944. $-645 \mathrm{p}$.

6. Мещеряков Н.Л. Международная кооперация / Н.Л. Мещеряков. - Москва : Государственное издательство, 1923. - 87 с.

7. Теория и история кооперативного движения / В.Н. Титаев, В.В. Петров, И.Ф. Бородин. Энгельс, 2002. - 348 с.

8. Полоцький О. Кооперація за червоним кордоном / О. Полоцький. - Харків : ДВУ, 1927. - 78 с.

9. Watkins W.P. International Cooperative Alliance 1895-1970 / W.P. Watkins - London, 1970 - 387 p.

10. Гавриленко Ю. М. Видатні діячі кооперативного руху та їх ідеї / Ю. М. Гавриленко / Мирослав Васильович Аліман [авт. упоряд.], Юрій Миколайович Гавриленко [авт. упоряд.]. - 2-е вид., перероб. та доп. - Донецьк: Проект, 2000. - 296 с. 
11. Бородаевский С.В. Сельскохозяйственная кооперация в Германии. -Санкт-Петербург : Спб., 1908. -60 c.

12. Вахитов К. И. Кооперация. Теория, история, практика: избранные изречения, факты, материалы, комментарии / К.И. Вахитов. - Москва : ИТК Дашков и Ко, 2004. - 556 с.

13. Вольф Г. Народные банки / Г. Вольф. - Москва: Типография Сытина, 1915. - 436 с.

14. Emelianoff Ivan V. (Reprinted 1995). Economic Theory of Cooperation: Economic Structure of Cooperative Organizations / Ivan V. Emelianoff. - Davis, CA : University of California, 1948. - 266 c.

15. Шилова Н. П. Организационно-правовые основы сельскохозяйственной кредитной кооперации в зарубежных странах / Н. П. Шилова // Труды филиала МГЮА в г. Вологде. -2004. - Вып. 1. - C. 141-164.

16. Тотомианц В. Кооперативная жизнь за границей / В. Тотомианц // Кооперативная жизнь. 1913. - № 3-4. - C. 14-16.

17. Fox W. The co-operatives in danger, Italy-Germany-England / W. Fox. - London : Labour Research Department, 1934. - № 51. - 15 p.

18. Доклад с XI-го конгресса МКА. - 1924. - С. 45. [Электронный ресурс]. - режим доступа : http://www.aim25.ac.uk.

19. Fox W. Who attacks co-operatives? / W. Fox. - London : Labour Research Department, 1934. №52. $-22 \mathrm{p}$.

20. Kornovenko S., Zemzyulina N. Revolutionary Disturbances in the Early XX Century: Agrarian Law of Central and South Eastern Europe / Kornovenko S., Zemzyulina N. // Український селянин. Черкаси, 2014. - Вип. 18. - С. 45-49.

\section{References}

1. Tugan-Baranovsky, M. I. (1989). Social fundamentals of cooperation. Moscow.: Ekonomika (in Russ.)

2. Flanagan, D. (1969). 1869-1969 A centenary story of the Co-operative Union of Great Britain and Ireland. Manchester: Co-operative union. Ltd (in Eng.)

3. Hall, F. \& Watkins, W. P. (1934). Co-operation: a survey of the history, principles and organisation of the co-operative movement in Great Britain and Ireland - London: Co-operative union. Ltd (in Eng.)

4. 4. Makarenko, A. P., Krashennikov, A. I., Kizilevich, A. V., Palamarchuk B. E., \& Khvostov B.N. (1982). Cooperation Theory M.: Economics (in Russ.)

5. Reeves, J. (1944 ). A century of Rochdale co-operation, 1844-1944 . London : Lawrence \& Wishart (in Eng.)

6. 6. Mesheryakov, N.L. ( 1923). International cooperation. Moscow.: State Publishing House (in Russ.)

7. Titayev, V. N., \& Petrov, V.V., Borodin, I. F. ( 2002 ). Theory and history of cooperative movement. Engels: RIIC PKI (in Russ.)

8. Polotskyi, O. (1927). Cooperation behind red border . Kh.: DVU (in Ukr.)

9. Watkins, W. P. (1970). International Cooperative Alliance 1895-1970. London: (in Eng.)

10. Havrykenko, Yu. M. (2000). Famous leaders of cooperative movement and their ideas / Yu.M. Havrylenko / Myroslav Vasyliovych Aliman, Yurii Mykolaiovych Havrylenko. - 2nd ed., revised and suppl. Donetsk: Project (in Ukr.)

11. Borodayevskiy, S. V. (1908). Agricultural cooperation in Germany . St. Petersburg: SPb Dep. Com a donkey. loan savings. and prom. t-wah, (in Russ.)

12. Vakhitov, K. I. (2004). Cooperation. Theory, history, practice: selected sayings, facts, materials, comments. M. : ITK Dashkov and Co (in Russ.)

13. Wolf, H. (1915). People's banks. Moscow.: Tipografiya Sytina. (in Russ.)

14. Emelianoff, Ivan V. (1948). (Reprinted 1995). Economic Theory of Cooperation : Economic Structure of Cooperative Organizations. Davis, CA : University of California (in Eng.)

15. Shylova, N.P. (2004). Organizational and legal fundamentals of agricultural credit cooperation in foreign countries. Works of MGYuA branch in Vologda. Iss. 1, 141-164 (in Russ.).

16. Totomianz, V. (1913). Cooperative life abroad. Cooperativne zhyttya (Cooperative life). 3-4, 14-16 (in Russ.).

17. Fox, W. (1934). The co-operatives in danger, Italy-Germany-England. London : Labour Research Department, 51, 1-15 (in Eng.)

18. Report from XI-th Congress of ICA. (1924) . - P. 45. (in Eng.) [Digital Source]. Retrieved from : http://www.aim25.ac.uk. 
19. Fox, W. (1934). Who attacks co-operatives?. London : Labour Research Department, 52, 1-22 (in Eng.)

20. Kornovenko, S., \& Zemzyulina, N. (2014). Revolutionary Disturbances in the Early XX Century: Agrarian Law of Central and South Eastern Europe Ukrainski Selianyn (Ukrainskyi Selianyn), Cherkasy, 18, 45-49 (in Ukr.)

ЗЕМЗЮЛІНА Наталка Іванівна, доктор історичних наук, професор, професор кафедри всесвітньої історії та міжнародних відносин Черкаського національного університету імені Богдана Хмельницького

КОРНОВЕНКО Сергій Валерійович, доктор історичних наук, професор, професор кафедри інтелектуальної власності та цивільно-правових дисциплін Черкаського національного університету імені Богдана Хмельницького

\section{РОЛЬ НАЦІОНАЛЬНИХ КООПЕРАЦІЙ В ЕКОНОМІЧНИХ ПЕРЕТВОРЕННЯХ СВРОПЕЙСЬКИХ ДЕРЖАВ У ПЕРШИЙ ТРЕТИНІ ХХ СТ. (НА ПРИКЛАДІ НІМЕЧЧИНИ)}

Дослідження присвячене особливостям кооперативного руху Німеччини, з метою показати як наиіональна кооперація в перехідний період зміни економічної моделі держави, стала дієвим інструментом по створенню майбутньої начіональної економічної системи. Незважаючи на існування з середини XIX ст. власних об'єднань міського населення Німеччини, котрі ставили собі за мету спільні закупівлі продуктів харчування, домінуючою була класична форма розвинутої споживчої кооперачї запозичена з досвіду британських рочдейльських товариств. Напередодні Першої світової війни, процеси випереджаючої індустріалізації та урбанізації німецького суспільства, перетворили переважно аграрну країну на провідну промислову державу Свропи та сприяли посиленню ролі німеиької споживчої кооперації у загальноєвропейській. Якщьо у галузі споживчої кооперації Німеччина наслідувала Велику Британію, то в галузі кооперачії кредитної виявилась батьківщиною двох ї̈ типів - міської Г. Шульце-Деліча та сільської Р. Райффайзена. Поширення кооперачії відбувалося з одного боку, шляхом врахування начіональних особливостей умов споживчої кооперачії, котра набувала водночас рис заготівельно-збутової або ощаднокредитних товариств Шульие-Деліча, з іншого ж боку, иляхом розвитку специифічної сільськогосподарської кооперації за принципами Райффайзена. Остання набере великої популярності в Свропі, модифікувавшись до потреб та суспільних настроїв кожної окремо взятої країни (Австро-Угорщина, Болгарія, Сербія, польські землі в складі Німецької імперії).

У перші десятиріччя XX cm. споживча кооперачія Західної Європи перейшла до етапу концентрації. За умов зростання обороту та чисельності членів, відбувається скорочення чисельності товариств внаслідок їх злиття. Консолідачія кооперативного руху відбувається $і$ в начіональному масштабі. Саме в Німеччині в 1902 р. було створено Імперський кооперативний сільськогосподарський банк. Варто відзначити, що селянство становило і більшість членів у Загальній спілці про-мислових та господарчих товариств (Шульие-Деліча). Остання, в першій третині XX ст. стала найбільшим осередком німецького кооперативного руху та вела активну міжнародну торгово-збутову діяльність за межсами континенту. Попри успішність розвитку сільськогосподарської кооперачії у Німеччині, в 30-х роках XX ст. ї̈ роль поступово зменшувалась, з огляду на швидку індустріалізачію та урбанізацію країни трансформувалась соціально база ї̈ членів. Погіршення економічного становища кооперативів стало предметом обговорення ХІІІ конгресу Міжнародного кооперативного альянсу, що проходив у 1930 рочі у Відні. На жаль, конгрес став черговий раз ареною ідеологічних боїв представників різних ідеологічних течій та партій і ніяких суттєвих рішень, по згуртуванню світової спільноти на захист кооперації не прийняв. Після приходу Гітлера до влади, кооперативні організачії Німеччини були включені до складу німеиького нацистського трудового фронту. Відбулось одержавлення кооперачії, з усіма негативними наслідками для самих принципів організащії та власності ї̈ членів.

Ключові слова: Німеччина, кооперативний рух, ощадно-кредитні товариства Шульие-Деліча, Райффайзенівські товариства. 